\title{
Pengaruh Pemanfaatan Aplikasi Google Classroom Terhadap Karakter Kemandirian dan Hasil Belajar Peserta Didik di Sekolah Menengah Pertama
}

\author{
Mahmuda Ma'arif, Mukhamad Murdiono \\ Universitas Negeri Yogyakarta
}

\begin{tabular}{l}
\hline INFO ARTIKEL \\
\hline Riwayat Artikel: \\
Diterima: $13-02-2021$ \\
Disetujui: $21-02-2021$ \\
\end{tabular}

\section{Kata kunci:}

Pembelajaran online

Google Classroom

Karakter Kemandirian

Hasil Belajar

PPKn

\section{ABSTRAK}

\begin{abstract}
This study aims to determine the effect of online learning using the Google Classroom application on the character of independence of students in junior high schools and to find out the effect of online learning using the Google Classroom application on student PPKn learning outcomes in junior high schools. The results showed that there was a significant effect of the use of the google classroom application on the independence character of grade VIII junior high school students and there was a significant effect of using the google classroom application on the level of learning outcomes of grade VIII SMP students.
\end{abstract}

\begin{abstract}
Abstrak: Penelitian ini bertujuan untuk mengetahui pengaruh pembelajaran online menggunakan aplikasi Google Classroom terhadap karakter kemandirian peserta didik di Sekolah Menengah Pertama dan mengetahui pengaruh pembelajaran online menggunakan aplikasi Google Classroom terhadap hasil belajar PPKn peserta didik di Sekolah Menengah Pertama. Hasil penelitian menunjukkan bahwa terdapat pengaruh signifikan dari penggunaan aplikasi google classroom terhadap karakter kemandirian peserta didik kelas VIII SMP dan terdapat pengaruh yang signifikan dari penggunaan aplikasi google classroom terhadap tingkat hasil belajar peserta didik kelas VIII SMP.
\end{abstract}

\section{Alamat Korespondensi:}

Mahmuda Ma'arif

Prodi Pendidikan Pancasila dan Kewarganegaraan

Program Pascasarjana UNY

Jl. Colombo Yogyakarta No.1, Karang Malang, Caturtunggal, Kec. Depok, Kabupaten Sleman, Daerah Istimewa

Yogyakarta 55281

Email: mukhamad_murdiono@uny.ac.id

\section{PENDAHULUAN}

Pendidikan bagi seorang manusia merupakan faktor penting guna menunjang perkembangan intelektual dan karakter. Pendidikan merupakan faktor utama yang membentuk pola pikir seorang individu. Hal itu dibuktikan dengan hasil penelitian (Sulisworo, 2016) yang menunjukkan bahwa pendidikan memiliki peran besar dalam membentuk sumber daya manusia yang berkualitas. Bahkan, berdasarkan temuan (Hanushek \& Woessmann, 2020) membuktikan bahwa kualitas pendidikan suatu negara sangat berpengaruh terhadap pertumbuhan perekonomian negara.

Pentingnya pendidikan bagi setiap anak harus disadari oleh semua pihak untuk dapat memberikan pendidikan yang tepat bagi setiap anak. Hal itu dikarenakan, proses pendidikan bagi seorang anak dapat terjadi secara formal atau nonformal. Proses pendidikan tersebut dikenal dengan pendidikan yang diperoleh dari tri pusat pendidikan yang terdiri dari pendidikan di keluarga, pendidikan di sekolah, dan pendidikan di lingkungan sosial 
masyarakat. Oleh karena itu, pendidikan di sekolah tidak dapat berjalan maksimal jika tidak didukung atau tidak sesuai dengan pendidikan yang diperoleh dari keluarga dan lingkungan sosial masyarakat.

Pendidikan di keluarga dan lingkungan sosial masyarakat merupakan pendidikan nonformal yang diperoleh anak dengan cakupan dan wawasan yang berbeda-beda. Hal itu dikarenakan, pendidikan nonformal di lingkungan keluarga dan lingkungan sosial masyarakat tidak memiliki standar minimal atau maksimal yang harus atau boleh diberikan kepada anak. Terlebih dengan perbedaan tingkat pendidikan antara orang tua satu dengan yang lainnya dan lingkungan sosial yang berbeda menimbulkan ketimpangan pendidikan nonformal bagi seorang anak.

Pendidikan formal di sekolah merupakan solusi untuk mengatasi ketimpangan yang terjadi di dalam proses pendidikan nonformal. Pendidikan di sekolah memiliki standar minimal dan standar maksimal sesuai tingkat pendidikan yang sedang di tempuh. Hal itu dikarenakan, guru yang ada di sekolah memiliki kriteria standar pendidikan yang merata. Bahkan, menurut (Gershenson, 2016; Tavakoli \& Baniasad-Azad, 2017) guru merupakan salah satu penentu keberhasilan hasil belajar peserta didik di sekolah yang terdiri dari keprofesionalan seorang guru, keterampilan dalam mengajar, dan iklim kelas yang tercipta. Oleh karena itu, pendidikan formal di sekolah memiliki peran yang sangat penting terhadap proses perkembangan intelektual dan karakter setiap peserta didik.

Pendidikan di sekolah tentunya harus menyesuaikan dengan perkembangan zaman. Perkembangan teknologi digital berbasis online ataupun offline merupakan perkembangan yang sedang terjadi sangat pesat di abad 21. Tentu tidak mengherankan jika pendidikan di sekolah ikut terdisrupsi oleh perkembangan zaman yang saat ini sedang terjadi sangat pesat dengan beralihnya beberapa sektor kehidupan manusia ke media digital. Hal itu sesuai dengan pernyataan (kasi Viswanath et al., 2012) bahwa perkembangan pendidikan di abad 21 sangat identik dengan perkembangan pendidikan yang memanfaatkan teknologi digital.

Revolusi industri 4.0 merupakan tema yang banyak digaungkan di berbagai kegiatan diskusi atau seminar pendidikan. Hal itu menandakan bahwa pendidikan di sekolah tengah mengalami perkembangan yang cukup pesat dalam upaya pemanfaatan teknologi digital. Sesuai dengan hasil penelitian (Davey et al., 2019; Lai \& Bower, 2019) bahwa penggunaan teknologi digital di dalam proses pembelajaran di sekolah bertujuan untuk meningkatkan efektivitas proses pembelajaran antara guru dan peserta didik, karena dapat menjadi solusi keterbatasan waktu, tempat, dan biaya yang digunakan untuk menciptakan proses pembelajaran konvensional.

Pandemik Covid 2019 merupakan salah satu pemicu penggunaan media digital dalam proses pembelajaran secara masif. Pandemik Covid 2019 mengharuskan setiap sekolah dapat melaksanakan proses pembelajaran berbasis online. Hal itu bertujuan mendukung upaya social distancing dan physical distancing anak didik agar tidak tertular Covid 2019. Oleh karena itu, hampir setiap sekolah di dunia menggunakan media belajar online dalam proses pembelajaran sekolah.

Hasil penelitian (Cambridge Assessment International Education, 2018) melalui Global Education Census membuktikan bahwa Indonesia memang telah menjadi salah satu pengguna media digital terbesar di dunia dalam bidang pendidikan. Siswa di Indonesia merupakan peringkat pertama penggunaan ruang komputer guna menunjang pembelajaran dengan persentase $40 \%$ dan berada di peringkat kedua untuk penggunaan komputer desktop dengan persentase 54\%. Bahkan $67 \%$ siswa di Indonesia menggunakan ponsel pintar di ruang kelas dan $81 \%$ menggunakan ponsel pintar untuk mengerjakan tugas di rumah. Data tersebut memberikan informasi bahwa, penggunaan teknologi digital dalam proses belajar mengajar di Indonesia memang telah mengalami peningkatan yang sangat signifikan, terlebih dengan pemicu pandemik Covid 2019 yang mendorong proses belajar mengajar dilangsungkan secara online.

Keharusan penggunaan media online di tengah pandemik Covid 2019 memicu banyak media pembelajaran online muncul dan berkembang untuk memfasilitasi proses pembelajaran anak didik. Namun, penggunaan media pembelajaran online banyak menuntut peserta didik belajar secara mandiri. Hal itu tentunya menuntut guru agar mampu menciptakan pembelajaran mandiri yang efektif bagi peserta didik walaupun proses pembelajaran tidak dapat dilaksanakan secara langsung. Salah satu media pembelajaran online yang banyak digunakan oleh guru di sekolah adalah aplikasi Google Classroom yang merupakan bagian dari perusahaan Google.

Aplikasi Google Classroom merupakan salah satu fitur dari pembelajaran digital yang sangat banyak digunakan oleh guru dan peserta didik dalam proses pembelajaran. Di SMP Muhammadiyah Pakem, Google Classroom merupakan aplikasi media pembelajaran yang paling banyak digunakan guru dan peserta didik dalam proses pembelajaran. Hal itu dikarenakan, banyak fitur pembelajaran yang mudah digunakan guru untuk merancang dan menciptakan pembelajaran yang memadai bagi peserta didik. Terlebih banyak guru dan peserta didik yang belum terbiasa menggunakan media pembelajaran online lain dalam proses pembelajaran. 
Banyak guru dan peserta didik di Indonesia yang masih sangat baru menggunakan media pembelajaran online dalam kegiatan pembelajaran. Terutama bagi para guru dan peserta didik yang berada pada jenjang pendidikan Dasar dan Menengah. Berbeda dengan jenjang pendidikan tinggi yang lebih kurang telah banyak menggunakan media pembelajaran online guna menunjang keterbatasan waktu dan efisiensi biaya belajar yang tentunya tidak memperngaruhi hasil belajar peserta didik. Oleh karena itu, masifnya penggunaan media pembelajaran online di sekolah dasar dan menengah dalam masa pandemik Covid -19 memerlukan karakter kemandiri peserta didik agar proses pembelajaran dapat berjalan secara maksimal.

Pendidikan Pancasila dan Kewarganegaraan merupakan salah satu mata pelajaran yang paling banyak bermuatan aspek afektif. Karakter mandiri merupakan salah satu dari aspek afektif yang menjadi tujuan proses pembelajaran di sekolah. Pelaksanaan pembelajaran secara jarak jauh menggunakan aplikasi Google Classroom merupakan tantangan bagi guru mata pelajaran Pendidikan Pancasila dan Kewarganegaraan guna menanamkan karakter mandiri kepada setiap peserta didik. Selain mencapai hasil belajar yang memuaskan bagi setiap peserta didik, guru juga harus mampu memberikan pendidikan karakter yang tepat bagi peserta didik. Terlebih guru pada mata pelajaran Pendidikan Pancasila dan Kewarganegaraan yang menjadi salah satu mata pelajaran yang paling banyak bermuatan moral.

Guru tentu tidak dapat mengontrol secara penuh kegiatan belajar mengajar dalam media belajar online. Sesuai dengan temuan (Wu et al., 2019) yang membuktikan bahwa peserta didik sering melakukan kesalahan dalam memahami materi dengan representasi yang berbeda. Hal itu tentu menjadi perhatian khusus bagi guru terhadap hasil belajar yang akan dicapai. Peran keluarga dalam hal ini wali murid harus bersedia dan cakap dalam mengontrol dan membimbing anak dalam proses pembelajaran berbasis online. Namun, permasalahannya tidak semua orang tua wali murid mumpuni dalam penggunaan media pembelajaran online. Oleh karena itu, proses pembelajaran menggunakan media pembelajaran online memiliki banyak faktor yang harus dipersiapkan berupa panduan prosedur yang lengkap guna menciptakan pembelajaran yang efektif (Lall et al., 2019).

Proses pembelajaran jarak jauh berbasis online yang tidak secara langsung bertatap muka merupakan tantangan besar bagi guru mata pelajaran Pendidikan Pancasila dan Kewarganegaraan. Hal itu dikarenakan, banyak nilai-nilai moral dan karakter yang terbiasa ditanamkan oleh guru Pendidikan Pancasila dan Kewarganegaraan dengan cara langsung dalam proses pembelajaran. Seperti berdoa sebelum dan sesudah pelajaran dimulai, mengucapkan Salam, menyanyikan lagu wajib dan lagi nasional, literasi membaca, dan berbagai macam pembiasaan yang masuk dalam program pendidikan karakter di sekolah.

Dampak dari era industri 4.0 dan dampak adanya pandemik Covid 2019 menuntut guru untuk kreatif dan cerdik dalam menyusun proses pembelajaran online yang efektif pada aspek afektif, kognitif, dan psikomotor. Tujuannya agar proses pembelajaran jarak jauh (Daring) dapat berjalan efektif dengan faktor kemandirian peserta didik. Karakter kemandirian merupakan salah satu aspek afektif yang sangat dibutuhkan peserta didik dalam proses belajar online dan kehidupan sosial masyarakat. Guru mata pelajaran Pendidikan Pancasila dan Kewarganegaraan merupakan guru yang harus ekstra kreatif dan cerdik guna menyusun proses pembelajaran yang efektif menanamkan karakter mandiri kepada setiap peserta didik guna menunjang proses pembelajaran pada mata pelajaran yang lain. Oleh karena itu, perlunya data empiris yang membuktikan dampak dan pengaruh yang diberikan proses pembelajaran berbasis media online menggunakan google classroom terhadap karakter kemandirian dan hasil belajar mata pelajaran Pendidikan Pancasila dan Kewarganegaraan peseta didik di sekolah.

Penelitian ini bertujuan untuk mengetahui pengaruh pembelajaran online menggunakan aplikasi Google Classroom terhadap karakter kemandirian peserta didik di Sekolah Menengah Pertama dan mengetahui pengaruh pembelajaran online menggunakan aplikasi Google Classroom terhadap hasil belajar PPKn peserta didik di Sekolah Menengah Pertama.

\section{MIETODE}

Penelitian ini merupakan jenis Quasi Experimental dengan menggunakan desain Posttest Control Group Design. Berjenis Experimental Design karena dalam penelitian ini sampel penelitian dipilih secara acak dengan pertimbangan cluster tertentu. Berjenis penelitian eksperimen karena dilakukan treatment kepada sampel penelitian pada kelas eksperimen. Treatment yang diberikan yaitu dengan melakukan pembelajaran menggunakan aplikasi Google Classroom dan diukur dampak dari treatment yang diberikan pada kelas eksperimen berdasarkan pengukuran di kelas kontrol. 
Tempat atau lokasi penelitian ini adalah SMP Muhammadiyah Pakem tahun ajaran 2020/2021. Pemilihan lokasi ini dilakukan dengan beberapa pertimbangan; Pertama, SMP Muhammadiyah Pakem Yogyakarta merupakan salah satu sekolah yang menerapkan proses pembelajaran online dengan menggunakan aplikasi Google Classroom . Kedua, Pola Pembinaan dan proses pembelajaran di SMP Muhammadiyah Pakem Yogyakarta meliputi penggabungan antara pengetahuan umum dan agama, yang berkorelasi dengan upaya penguatan karakter mandiri peserta didik.

Penelitian ini dilakukan dilakukan pada bulan Juli sampai November 2020, setelah penulis memenuhi persyaratan-persyaratan dalam perizinan penelitian. Pemilihan waktu penelitian berdasarkan kondisi dan pelaksanaan proses pembelajaran menggunakan aplikasi Google Classroom di sekolah. Sampel penelitian merupakan bagian dari populasi yang mempunyai karakteristik sama dengan populasi dari penelitian yang dilakukan. Penentuan sampel penelitian ini dilakukan dengan menggunakan teknik cluster random sampling yang mempertimbangkan kesetaraan karakter dan saran dari guru di sekolah. Adapun jumlah sampel penelitian ini adalah dua kelas dengan jumlah 66 peserta didik dengan 23 peserta didik merupakan kelas eksperimen dan 23 peserta didik merupakan kelas kontrol.

Teknik pengumpulan data yang digunakan dalam penelitian ini yaitu dengan menggunakan tes karakter melalui angket sikap dan tes hasil belajar yang diberikan kepada setiap sampel penelitian. Instrumen pengumpulan data dalam penelitian ini digunakan tes karakter kemandirian peserta didik menggunakan angket. Teknik analisis data pada penelitian "Pengaruh Pemanfaatan Aplikasi Google Classroom Terhadap Karakter Kemandirian Peserta Didik Di Sekolah Menengah Pertama." dilakukan dengan menggunakan uji statistik parametrik uji-t.

\section{HASIL}

\section{Hasil Uji Pengaruh Penggunaan Google Classroom Terhadap Hasil Belajar Pesert Didik}

Pada tahap ini dilakukan uji hipotesis dengan menggunakan uji statistik piered-sample $t$ test. Uji statistik piered-sample $t$ test merupakan uji statistik parametrik yang memiliki prasyarat data harus normal dan homogen. Hal tersebut telah terpenuhi dengan terbuktinya data penelitian tes hasil belajar dalam penelitian ini berasal dari populasi yang homogen dan data yang berdistribusi normal. Bukti uji prasyarat tersebut dapat dilihat pada tabel 2 dan tebel 4. Adapun hipotesis yang di uji dalam uji hipotesis ini adalah.

$\mathrm{H}_{\mathrm{a}}$ : Terdapat perbedaan tingkat hasil belajar PPKn peserta didik kelas VIII SMP sebelum dan sesudah proses pembelajaran

$\mathrm{H}_{0}$ : Tidak terdapat perbedaan tingkat hasil belajar PPKn peserta didik kelas VIII SMP sebelum dan sesudah proses pembelajaran

Pengambilan kesimpulan dalam uji hipotesis dengan uji statistik piered-sample $t$ test dilakukan dengan menggunakan taraf signifikansi 0,05. Kriteria tersebut memberikan ketentuan pengambilan kesimpulan bahwa jika nilai signifikansi yang diperoleh $<0,05$ maka $\mathrm{H}_{a}$ diterima dan $\mathrm{H}_{0}$ ditolak. Hasil uji statistik piered-sample t test dapat dilihat pada Tabel 1.

Tabel 1. Hasil analisis uji statistik Paired Samples Test

\begin{tabular}{lccccc}
\hline \multicolumn{1}{c}{ Data } & T hitung & T tabel & Sig. (2-tailed) & Sig 5\% & Simpulan \\
\hline Kelas Eksperimen & -22.307 & $-2,037$ & 0.000 & 0,05 & Ada Perbedaan \\
Kelas kontrol & -14.135 & $-2,037$ & 0.000 & 0,05 & Ada Perbedaan \\
\hline
\end{tabular}

Berdasarkan hasil uji statistik Paired Samples Test membuktikan bahwa terdapat perbedaan tingkat hasil belajar peserta didik sebelum dan sesudah proses pembelajaran di kelas kontrol dan kelas ekseperimen. Hasil uji statistik Paired Samples Test pada kelas kontrol diperoleh nilai Sig. (2-tailed) $0.000<0,05$ maka $\mathrm{H}_{\mathrm{a}}$ diterima dan $\mathrm{H}_{0}$ ditolak yang artinya "terdapat perbedaan tingkat hasil belajar PPKn peserta didik kelas VIII SMP sebelum dan sesudah proses pembelajaran". Hasil yang diperoleh kelas kontrol dibandingkan dengan hasil uji statistik Paired Samples Test di kelas eksperimen. Hasil uji statistik Paired Samples Test pada kelas eksperimen diperoleh nilai Sig. (2-tailed) $0.000<0,05$ maka $\mathrm{H}_{\mathrm{a}}$ diterima dan $\mathrm{H}_{0}$ ditolak yang artinya "terdapat perbedaan tingkat hasil belajar PPKn peserta didik kelas VIII SMP sebelum dan sesudah proses pembelajaran”.

Berdasarakan hasil uji statistik Paired Samples Test dapat disimpulkan bahwa terdapat pengaruh antara variabel (independent) penggunaan aplikasi google classroom terhadap variabel (dependent) hasil belajar peserta 
didik kelas VIII pada kelas eksperimen. Namun, berdasarkan data hasil uji statistik Paired Samples Test perbedaan tingkat hasil belajar peserta didik tidak hanya terjadi di kelas eksperimen, tetapi juga terjadi di kelas kontrol. Hal itu memberikan penjelasan bahwa proses pembelajaran biasa juga memiliki pengaruh terhadap peningkatan hasil belajar peserta didik di kelas kontrol. Bukti diterimanya Ha pada uji statistik Paired Samples Test di kelas kontrol dan kelas eksperimen dapat dilihat pada tabel 6.

Berdasarkan Tabel 1 membuktikan bahwa t hitung $<\mathrm{t}$ tabel yang Ha diterima dan H0 ditolak. Hasil tersebut membuktikan adanya pengaruh yang diberikan atau peningkatan hasil belajar peserta didik di kelas kontrol dan kelas eksperimen pada peserta didik. Hasil pengujian hipotesis tersebut membuktikan bahwa dari dua proses pembelajaran atau dua treatment kepada peserta didik di kelas eksperimen dengan google classroom dan peserta didik di kelas kontrol tanpa google classroom berpengaruh terhadap hasil belajar peserta didik.

Hasil analisis tersebut belum memberikan informasi yang manakan proses pembelajaran yang lebih efektif antara proses pembelajaran di kelas eksperimen dan kelas kontrol. Oleh karena itu, pengambilan kesimpulan tingkat pengaruh diambil dari perbandingan peningkatan nilai rata-rata tes hasil belajar peserta didik di kelas eksperimen dan kelas kontrol. Berdasarakan hasil uji deskriptif Paired Samples Test diketahii bahwa peningkatan nilai (Mean) atau rata-rata lebih besar terjadi di kelas eksperimen jika dibandingkan dengan penigkatan nilai (Mean) atau rata-rata di kelas kontrol. Hasil uji statistik deskriptif Paired Samples Test kelas kontrol dan kelas eksperimen dapat dilihat pada Tabel 2.

Tabel 2. Statistik deskriptif Paired Samples Test

\begin{tabular}{|c|c|c|c|c|c|}
\hline \multicolumn{6}{|c|}{ Paired Samples Statistics } \\
\hline & & Mean & $\mathbf{N}$ & Std. Deviation & Std. Error Mean \\
\hline \multirow[t]{2}{*}{ Pair 1} & Pre-Test Kontrol & 63.18 & 33 & 8.644 & 1.505 \\
\hline & Post Test Kontrol & 68.03 & 33 & 8.380 & 1.459 \\
\hline \multirow[t]{2}{*}{ Pair 2} & Pre-Test Eksperimen & 64.09 & 33 & 8.701 & 1.515 \\
\hline & Post Test Eksperimen & 79.39 & 33 & 8.456 & 1.472 \\
\hline
\end{tabular}

Peningkatan nilai rata-rata (Mean) pada kelas eksperimen sebesar 15,30, sedangkan peningkatan nilai ratarata (Mean) pada kelas kontrol adalan sebesar 4,85. Peningkatan nilai rata-rata tersebut membuktikan bahwa proses pembelajaran dengan menggunakan google classroom pada kelas eksperimen lebih berpengaruh terhadap peningkatan hasil belajar peserta didik di bandingkan dengan proses pembelajaran biasa atau yang tidak menggunakan google classroom pada kelas kontrol. Bukti lebih berpengaruhnya proses pembelajaran unakan google classroom pada kelas eksperimen dibandingkan proses pembelajaran biasa atau yang tidak menggunakan google classroom pada kelas kontrol adalah $(15,30>4,85)$. Hasil pengujian hipotesis melalui uji Paired Samples Test membuktikan bahwa penggunaan aplikasi google classroom berpengaruh signifikan terhadap hasil belajar peserta didik kelas VIII SMP.

\section{Pengujian Tingkat Kemandirian}

Pada tahap ini dilakukan uji hipotesis bahwa proses pembelajaran peserta didik dengan menggunakan aplikasi google classroom berpengaruh signifikan terhadap karakter kemandirian peserta didik. Pengujian tingkat pengaruh yang diberikan oleh treatment proses pembelajaran menggunakan aplikasi google classroom dilakukan dengan menggunakan penginterpretasian nilai (mean) atau rata-rata skor kemandirian responden terhadap interval skor kemandirian. Interval skor kemandirian peserta didik dalam penelitian ini dapat dilihat pada Tabel 3.

\begin{tabular}{ccl}
\multicolumn{4}{c}{ Tabel 3. Interval Skor Kemandirian } \\
\hline No & Interval & \multicolumn{1}{c}{ Kategori } \\
\hline 1 & $58,9-70$ & Sangat Mandiri \\
2 & $47,6-58,8$ & Mandiri \\
3 & $36,5-47,6$ & Cukup Mandiri \\
4 & $25,3-36,4$ & Kurang Mandiri \\
5 & $14-25,2$ & Sangat Tidak Mandiri \\
\hline
\end{tabular}

Berdasarkan interval skor kemandirian pada Tabel 3, hasil pengujian tingkat kemandirian peserta didik di kelas eksperimen dan kelas kontrol dapat dibandingkan melalui interval skor kemandirian pada tabel 8. Dari hasil tes penilaian diri membuktikan bahwa tingkat kemandirian peserta didik setelah proses pembelajaran atau 
treatmen dengan menggunakan aplikasi google classroom di kelas eksperimen memiliki rata-rata tingkat kemandirian yang lebih tinggi dibandingkan dengan rata-rata tingkat kemandirian peserta didik di kelas kontrol yang hanya diberi treatment proses pembelajaran biasa tanpa ada pembiasaan belajar mandiri.

Hasil perhitungan nilai Mean dari skor kemandirian peserta didik di kelas kontrol dan kelas eksperimen diperoleh nilai 61.27273 untuk kelas eksperimen setelah treatmen dengan menggunakan aplikasi google classroom dan diperoleh nilai 43.9697 untuk kelas kontrol setelah treatmen tanpa menggunakan aplikasi google classroom. Hal itu membuktikan bahwa tingkat kemandirian peserta didik pada kelas eksperimen lebih tinffi jika dibandingkan dengan tingkat kemandirian peserta didik di kelas kontrol setelah proses pembelajaran yang menggunakan aplikasi google classroom dan tidak. Hasil analis data tes penilaian diri dapat dilihat pada Tabel 4.

Tabel 4. Tes Penilaian Diri Peserta Didik

\begin{tabular}{lccc}
\hline \multicolumn{1}{c}{ Kelas } & Nilai Mean & Interval & Kategori \\
\hline Eksperimen & 61.27273 & $58,9-70$ & Sangat Mandiri \\
Kontrol & 43.9697 & $36,5-47,6$ & Cukup Mandiri \\
\hline
\end{tabular}

Berdasarkan skor rata-rata nilai kemandirian peserta didik di kelas eksperimen pada Tabel 4 diketahui bahwa kategori skor kemandirian peserta didik di kelas eksperimen berada pada kategori "sangat mandiri" sesuai dengan interpretasi nilai mean pada Tabel 4 kepada tabel 8. Untuk kelas kontrol, berdasarkan nilai mean pada Tabel 4 diketahui bahwa kategori skor kemandirian peserta didik kelas kontrol hanya berada pada kategori "cukup mandiri”. Data hasil analisis tersebut membuktikan bahwa $\mathrm{H}_{\mathrm{a}}$ diterima dan $\mathrm{H}_{0}$ ditolak yang artinya terdapat pengaruh yang signifikan penggunaan aplikasi google classroom dalam proses pembelajaran PPKn di kelas VIII SMP terhadap karakter kemandirian peserta didik.

Hasil analisis data penilaian diri peserta didik berdasarkan interpretasi nilai mean skor kemandirian dibuktikan dengan uji statistik Independent Sample $t$ test. Hasil uji Independent Sample t test membuktikan bahwa terdapat perbedaan yang signifikan antara skor kemandirian peserta didik di kelas eksperimen dan kelas kontrol. Hal itu didasarkan kepada hasil uji statistik Independent Sample $t$ test yang diperoleh nilai signifikansi pada Levene's Test for Equality of Variances adalah 0.007 dan nilai signifikansi pada t-test for Equality of Means adalah 0.000. Hasil uji statistik Independent Sample t test dapat dilihat pada Tabel 5.

Tabel 5. Hasil uji statistik Independent Sample t test

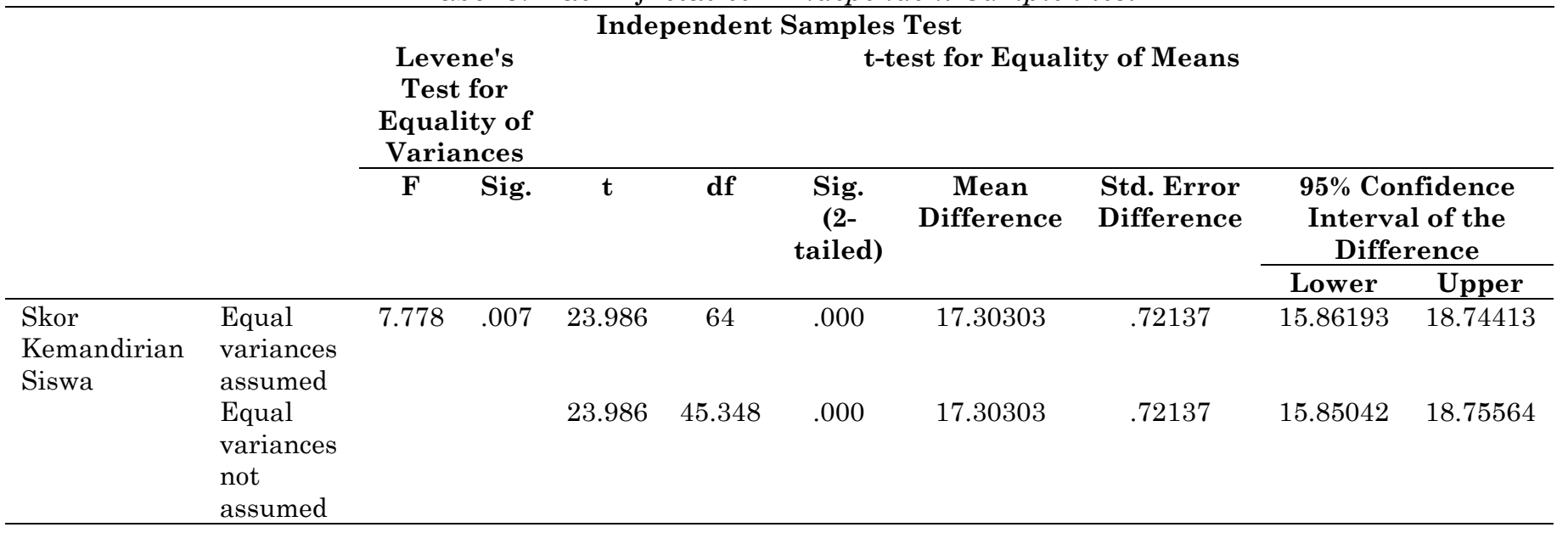

Berdasarkan data pada Tabel 5 Membuktikan bahwa terdapat perbedaan yang signifikan antara tingkat kemandirian peserta didik di kelas eksperimen yang telah diberi treatment pembelajaran dengan menggunakan aplikasi google classroom dan peserta didik di kelas kontrol yang diberi treatment pembelajaran biasa. Dari hasil uji statistik Independent Sample t test diperoleh nilai Sig. (2-tailed) $0.000<0.05$ yang berarti $\mathrm{H}_{\mathrm{a}}$ diterima dan $\mathrm{H}_{0}$ ditolak. Hal itu memberikan bukti bahwa proses pembelajaran dengan menggunakan aplikasi google classroom pada kelas eksperimen berpengaruh signifikan terhadap karakter kemandirian peserta didik yang lebih baik dibandingkan dengan proses pembelajaran biasa di kelas kontrol. 
PEMBAHASAN

\section{Pengaruh Penggunaan Google Classroom Terhadap Hasil Belajar}

Berdasarkan hasil analisis data yang telah dilakukan pada data penelitian tes hasil belajar peserta didik, diketahui bahwa peningkatan hasil belajar peserta didik di kelas eksperimen lebih baik dibandingkan peningkatan hasil belajar peserta didik di kelas kontrol. Hal itu dibuktikan dengan hasil analisis uji ststitik Paired Samples Test pada kelas kontrol dan kelas ekseprimen diperoleh nilai Sig. (2-tailed) $0.000<0,05$ untuk kelas eksperimen dan diperoleh nilai Sig. (2-tailed) $0.000<0,05$ untuk kelas eksperiman. Hal itu memberikan bukti bahwa $\mathrm{H}_{\mathrm{a}}$ diterima dan $\mathrm{H}_{0}$ ditolak untuk data tes hasil belajar di dua kelas tersebut yang artinya "terdapat perbedaan tingkat hasil belajar PPKn peserta didik kelas VIII SMP sebelum dan sesudah proses pembelajaran”.

Hasil tersebut sesusi dengan hasil analisis nilai mean dari masing-masing kelas penelitian. Pada kelas eksperimen terjadi peningkatan nilai mean yang lebih besar dengan jumlah peningkatan nilai mean hasil belajar sebesar 15,30. Peningkatan nilai mean tersebut lebih besar jika dibandingkan dengan peningkatan nilai mean hasil belajar peserta didik di kelas kontrol yang hanya meningkat sebesar 4,85. Nilai mean tersebut merupakan nilai mean yang diperoleh dari pelaksanaan ujian atau tes hasil belajar di kelas ekseperimen dan kelas kontrol untuk tes hasil belajar saat pretest dan posttest.

Berdasarkan hasil uji analisis data tersebut dapat disimpulkan bahwa proses pembelajaran dengan menggunakan aplikasi google classroom pada proses pembelajaran daring terbukti lebih efektif meningkatkan hasil belajar peserta didik di bandingkan dengan penggunaan media lain atau media konvensional untuk proses pembelajaran biasa di sekolah SMP kelas VIII. Hal itu sesuai dengan hasil penelitian dari (Arruji, 2020) yang membuktikan bahwa penggunaan aplikasi google classroom memiliki pengaruh yang signifikan terhadap hasil belajar peserta didik.

Hasil penelitian tersebut mendukung hasil analisis data penelitian ini. (Windriyani, 2019) dari hasil penelitiannya juga memberikan bukti yang sama bahwa proses pembelajaran jarak jauh atau dikenal dengan proses pembelajaran daring dengan menggunakan aplikasi google classroom memiliki tingkat efektivitas yang tidak kalah dengan proses pembelajaran konvensional secara langsung di dalam kelas. Terlebih jika guru dapat meninjau dari proses dan aktivitas belajar peserta didik dalam proses pembelajaran.

Beberapa hasil penelitian tersebut memperoleh hasil yang selaras dengan hasil penelitian ini. Hal itu membuktikan bahwa penggunaan media belajar online seperti google classroom memang dapat menjadi solusi bagi para guru atau praktisi pendidikan lain untuk tetap dapat menjalankan proses pembelajaran yang efektif dan layak bagi peserta didik pada waktu-waktu atau kondisi yang tidak memungkinkan untuk dilaksanakan proses pembelajaran secara tatap muka di sekolah. Bahkan berdasarkan hasil penelitian dari (Santoso \& Marzuki, 2020)memberikan referensi bagi guru bahwa proses evaluasinya pun dapat dilaksanakan secara online atau jarak jauh. Hal itu tentu mendukung jalannya proses pembelajaran online yang tentunya tidak dapat melaksanakan evaluasi pembelajaran secara langsung.

Hasil penelitian lain membutikan bahwa penggunaan google classroom dalam proses pembelajaran di sekolah memiliki pengaruh terhadap hasil belajar peserta didik. Berdasarkan hasil analisis data penelitian dan analisis dari review beberapa hasil penelitian terdahulu maka dapat disimpulkan bahwa penggunaan aplikasi google classroom berpengaruh terhadap peningkatan hasil belajar PPKn peserta didik kelas VIII SMP yang di dukung dengan beberapa hasil penelitian terdahulu yang juga memperoleh hasil yang sama pada meteri dan mata pelajaran yang berbeda.

\section{Pengaruh Penggunaan Google Classroom Terhadap Karakter Kemandirian}

Berdsarakan analisis data pada data penelitian tes penilaian diri, diketahui bahwa tingkat kemandirian peserta didik di kelas eksperimen lebih tinggi dibandingkan dengan tingkat kemandirian peserta didik di kelas kontrol. Hal itu diketahui berdasarkan hasil analisis data secara statistik dengan menggunakan metode ji statistik Independent Sample t test. Hasil uji statistik Independent Sample $t$ test membuktikan bahwa terdapat perbedaan yang signifikan antara tingkat kemandirian peserta didik di kelas eksperimen dan kelas kontrol setelah dilaksanakan proses pembelajaran.

Hasil uji statistik Independent Sample $t$ test diperoleh nilai Sig. (2-tailed) $0.000<0.05$ yang berarti $\mathrm{H}_{\mathrm{a}}$ diterima dan $\mathrm{H}_{0}$ ditolak. Hal itu membuktikan bahwa terdapat perbedaan yang signifikan antara tingkat 
kemandirian peserta didik di kelas eksperimen dan kelas kontrol setelah dilakukan treatment menggunakan aplikasi google classroom di kelas eksperimen dan tanpa google classroom di kelas kontrol.

Tingginya tingkat karakter kemandirian peserta didik di kelas eksperimen dikarenakan, peserta didik lebih terbiasa dengan proses belajar mandiri melalui proses belajar jarak jauh menggunakan aplikasi google classroom. Hal itu mengartikan bahwa pembelajaran dengan menggunakan aplikasi google classroom dapat menjadi salah satu faktor pembiasaan peserta didik untuk belajar mandiri dalam belajar ataupun kegiatan lainnya. Karena, sebagaimaimana yang dinyatakan oleh (Santoso et al., 2018) bahwa penumbuhan karakter kemandirian peserta didik dimulai dari tahap pembiasaan, pengembangan, dan pengaktualisasian sebagaimana yang dilakukan dalam program gerakan literasi sekolah.

Hasil penelitian (Mayasari et al., 2016; Yuliati \& Saputra, 2020) DAN HUDA membuktikan bahwa pelaksanaan pembelajaran daring dengan metode blanded learning menggunakan media google classroom memberikan pengaruh terhadap peningkatan kemampuan belajar mandiri peserta didik. Begitupun hasil penelitian (Izzati \& Kuswanto, 2019) yang membuktikan pengaruh proses pemberlajaran blanded learning terhadap kemandirian pribadi peserta didik. Hal itu dikarenakan, peserta didik dituntut untuk selalu berkerja kerasa secara mandiri mengerjakan tugas pembelajaran dari proses pembelajaran jarak jauh. Oleh karena itu, orang tua cukup memafasilitasi dan mendampingi proses pembelajaran jarak jauh, tanpa harus ikut ataupun menggantikan posisi anak dalam mengerjakan tugas dari sekolah.

Tujuannya untuk meningkatkan efektifitas pembelajaran jarak jauh terhadap peningkatan kemandirian peserta didik. Hasil penelitian (Sabirin \& Sulistiyarini, 2020) membuktikan bahwa selain menjadi solusi dalam proses pembelajaran langsung yang terhambat, pembelajaran jarak jauh juga menjadi salah satu bentuk pembelajaran yang efektif terhadap sikap peserta didik dalam berkomunikasi digital. Hal tersebut tentunya sangat positif, dikarenakan banyak dari anak usia sekolah yang terlanjur salah dalam menggunakan media internet.

Hasil analisis uji Independent Sample t test sesuai dengan hasil analisis interpretasi nilai mean dari skor kemandirian peserta didik pada tes penilaian diri. Hasil nilai mean menunjukan bahwa peserta didik di kelas eksperimen memiliki nilai mean kemandirian sebesar 61.27273. Sedangkan nilai mean menunjukan bahwa peserta didik di kelas kontrol memiliki nilai mean kemandirian sebesar 43.9697.

Nilai mean tersebut, merupakan nilai mentah yang perlu di interpretasikan kedalam interval tingkat kemandirian peserta didik di sekolah. berdasarkan interpretasi nilai mean pada tabel 8, diketahui bahwa tingkat kemandirian peserta didik di kelas eksperimen berada pada kategori sangat mandiri, sedangkan tingkat kemandirian peserta didik di kelas kontrol berada pada kategori cukup mandiri.

Berdasarkan hasil interval kategori tersebut, dapat disimpulkan bahwa pembelajaran di kelas eksperimen memiliki tingkat keberhasilan yang lebih baik terhadap pembentukkarakter kemandirian peserta didik. Hal itu sesiai dengan hasil penelitian (Ellyandhani, 2020)bahwa proses pembelajaran yang dilaksanakan dengan media google classroom berpengaruh terhadap meningkatnya karakter kemandirian peserta didik di sekolah. Hasil penelitian tersebut membuktikan dan selaras dengan hasil uji statistik Independent Sample $t$ test bahwa proses pembelajaran di sekolah dengan menggunakan media belajar online google classroom memiliki pengaruh yang signifikan terhadap karakter kemandirian peserta didik. oleh karena itu, dapat disintesiskan bahwa proses pembelajaran jarak jauh dengan menggunakan aplikasi google classroom berpengaruh terhadap pembentukan karakter kemandirian peserta didik di sekolah.

\section{SIMIPULAN}

Terdapat pengaruh signifikan dari penggunaan aplikasi google classroom terhadap karakter kemandirian peserta didik kelas VIII SMP. Hal itu ditunjukan dengan tingginya nilai mean dari tes penilaian diri peserta didik di kelas eksperimen (61.27273) yang berada pada interval kategori sangat mandiri. Hal tersebut dikarenakan, melalui proses pembelajaran jarak jauh menggunakan aplikasi google classroom, peserta didik dibiasakan belajar secara mandiri melalu tugas-tugas yang diberikan oleh guru pada saat proses pembelajaran berlangsung. Terdapat pengaruh yang signifikan dari penggunaan aplikasi google classroom terhadap tingkat hasil belajar peserta didik kelas VIII SMP. Hal itu dibuktikan dengan uji statitik Paired Samples Test yang diperoleh nilai signifikansi 0,000 $<0,05$. Hal itu mengartikan bahwa penggunaan aplikasi google classroom berpengaruh signifikan terhadap peningkatan hasil belajar peserta didik. Bahkan, berdasarkan perbandingan nilai mean dari masing-masing hasil belajar di kelas kontrol dan kelas eksperimen, diketahui bahwa peningkatan nilai mean lebih besar terjadi di kelas 
eksperimen jika di bandingkan dengan kelas kontrol $(15,30>4,85)$. Hal itu membuktikan bahwa penggunaan aplikasi google classroom terbukti lebih berpengaruh dan lebih efektif meningkatkan hasil belajar peserta didik karena peserta didik teribiasa belajar mandiri melalui tugas-tugas yang diberikan guru.

\section{DAFTAR RUJUKAN}

Arruji, E. (2020). Pengaruh media google classroom terhadap hasil belajar pada Konsep Sistem Gerak. Jakarta: FITK UIN Syarif idayatullah Jakarta.

Cambridge Assessment International Education. (2018). Global Educational Census Report 2018.

Davey, B., Elliott, K., \& Bora, M. (2019). Negotiating pedagogical challenges in the shift from face-to-face to fully online learning: A case study of collaborative design solutions by learning designers and subject matter experts. Journal of University Teaching and Learning Practice, 16(1), 3-20.

Ellyandhani, L. A. (2020). Pengaruh model Blended Learning berbantu google classroom terhadap kemampuan berpikir kreatif dan kemandirian belajar peserta didik kelas xi mata pelajaran biologi di Sma Al-Azhar 3 bandar lampung. UIN Raden Intan Lampung.

Gershenson, S. (2016). Linking teacher quality, student attendance, and student achievement. Education Finance and Policy, 11(2), 125-149.

Hanushek, E. A., \& Woessmann, L. (2020). Education, knowledge capital, and economic growth. The Economics of Education, 171-182.

Izzati, M., \& Kuswanto, H. (2019). Pengaruh model pembelajaran blanded learning berbantuan kahoot terhadap motivasi dan kemandirian siswa. EDUMATIC: Jurnal Pendidikan Informatika, 3(2), 68-75.

kasi Viswanath, M. D., Kusuma, S., \& Gupta, S. K. (2012). Cloud computing issues and benefits modern education. Global Journal of Computer Science and Technology, 7(10), 14-20.

Lai, J. W., \& Bower, M. (2019). How is the use of technology in education evaluated? A systematic review. Computers \& Education, 133(2019), 27-42.

Lall, P., Rees, R., Law, G. C. Y., Dunleavy, G., Cotič, Ž., \& Car, J. (2019). Influences on the implementation of mobile learning for medical and nursing education: qualitative systematic review by the Digital Health Education Collaboration. Journal of Medical Internet Research, 21(2), e12895.

Mayasari, F., Santoso, S., \& Octoria, D. (2016). Upaya meningkatkan kemandirian belajar siswa melalui penerapan blended learning berbantuan Quipper School. Jurnal Tata Arta, 2(3), 159.

Sabirin, F., \& Sulistiyarini, D. (2020). Perbandingan blended learning dan Face-To-Face Learning terhadap kemampuan komunikasi mahasiswa pada proyek desain website. Edukasi: Jurnal Pendidikan, 18(1), 86-100.

Santoso, R., \& Marzuki, M. (2020). Assessment of learning outcomes based on Google Forms to reduce paper use. Teacher Education and Professional Development In Industry 4.0: Proceedings of the 4th International Conference on Teacher Education and Professional Development (InCoTEPD 2019), 13-14 November, 2019, Yogyakarta, Indonesia, 296.

Santoso, R., Pitoewas, B., \& Nurmalisa, Y. (2018). Pengaruh program literasi sekolah terhadap minat baca peserta didik SMAN 2 Gadingrejo. Jurnal Kultur Demokrasi, 7(1).

Sulisworo, D. (2016). The Contribution of the education system quality to improve the nation's competitiveness of Indonesia. Journal of Education and Learning, 10(2), 127-138.

Tavakoli, M., \& Baniasad-Azad, S. (2017). Teachers' conceptions of effective teaching and their teaching practices: a mixedmethod approach. Teachers and Teaching, 23(6), 674-688.

Windriyani, W. (2019). Pengaruh Media Google Classroom terhadap hasil belajar siswa ditinjau dari aktivitas belajar pada pelajaran Ekonomi Kelas X MAN 1 Banyumas. Universitas Jenderal Soedirman.

Wu, S. P., Corr, J., \& Rau, M. A. (2019). How instructors frame students' interactions with educational technologies can enhance or reduce learning with multiple representations. Computers \& Education, 128, 199-213.

Yuliati, Y., \& Saputra, D. S. (2020). Membangun kemandirian belajar mahasiswa melalui Blended Learning di masa pandemi covid-19. Jurnal Elementaria Edukasia, 3(1). 